\title{
Paweł Wacek
}

Faculty of Economic Sciences, Wroclaw University of Economics, Poland

\section{BARRIERS FOR THE DEVELOPMENT OF TRANSPORT OF TRAILERS AND TRUCKS BY RAIL IN POLAND}

\begin{abstract}
The idea of developing sustainable transport in Europe promotes ecological forms of transport. One of such solutions is the transport of trailers and trucks in rail traffic. The development of this form of intermodal transport encounters many barriers of legal and organizational nature, cost and resulting from time of service provision. Increasing the competitiveness of intermodal transport, in particular the transport of trailers and trucks in Poland, may take place through a series of activities of an investment and administrative nature by the infrastructure manager of PKP PLK S.A. and of a legal nature by the authorities of the country.

Keywords: intermodal transport, sustainable mobility, barriers of railway development, road and railway transport in Poland
\end{abstract}

\section{Introduction}

The development of transport and the intensification of transport processes, in particular road transport, lead to negative extern effects in the form of degradation of the natural environment, noise, air pollution and congestion. In the transport and economic policies of developed countries as well as integration groups, the idea of sustainable development of transport gains in importance. The idea of sustainable transport assumes such a development of transport that will satisfy the current transport needs and mobility without compromising the ability of future generations to meet these needs ${ }^{1}$. The $\mathrm{OECD}^{2}$ has adopted the definition of a sustainable transport system as such that does not threaten public health and the ecosystem

1 W.R. Black, Sustainable Transportation: A U.S. Perspective, Journal of Transport Geography 2006, 4, p. 151-159.

2 OECD Guidelines towards Environmentally Sustainable Transport, OECD, Paris 2002, p. 16. 
and meets the need for access to transport, compatible with the use of renewable energy below the regeneration threshold, and the use of non-renewable energy resources below the development threshold of renewable substitutes. One of the objectives of the European Commission is to reduce the negative effects associated with mobility. This means, above all, promoting co-modality, i.e. the optimal combination of different modes of transport within the same transport chain. Much more technical innovation and the shift to the least polluting and most energy-efficient means of transport will contribute to more sustainable mobility ${ }^{3}$. One of the transport modes promoting co-modality and limiting the external costs of transport is the transport of trailers and trucks by rail.

The purpose of this article is to identify barriers to the development of transport of trailers and trucks by rail and to propose recommendations reducing restrictions and allowing to strengthen the competitiveness of intermodal transport in Poland.

\section{Sustainable transport in selected EU documents}

Intermodal transport is understood as the carriage of freight in one and the same vehicle or cargo unit (without transshipment) using various modes of transport ${ }^{4}$. Due to the type of cargo units used, it can be divided into the transport of containers, trailers, swap bodies, trucks and special containers ${ }^{5}$. The subject of interest in this study is the transport of trailers and trucks by rail.

Intermodal transport is one of the most important elements of the construction of a sustainable transport system and is an ecological alternative for the majority of road transport of freight. The role of intermodal/rail transport has been emphasized in the latest EU 2020 strategy of $2010^{6}$ and in the most recent transport document, i.e. the White Paper of Transport from $2011^{7}$.

One of the initiatives enshrined in the White Paper on road transport is the alignment of legislation (guaranteeing) that it facilitates the use of intermodal transport and the reduction of total energy consumption and emissions. Among the ten objectives to create a competitive and resource efficient transport system, the following was written: "By 2030, 30\% of road freight over distances greater than $300 \mathrm{~km}$ should be transferred to other modes of transport, such as rail or water transport, and by 2050 this should more than $50 \%$ of this type of transport 'and' completing the fast European rail network by 2050. Three times increasing the existing high-speed rail network by 2030 and maintaining a dense railway network

3 European Commision, Sustainable transport, https://ec.europa.eu/transport/themes/sustainable_en (access: 18.02.2018).

4 Economic Commission for Europe, Terminology on combined transport, New York/Geneva 2001, http:// www.unece.org/trans/wp24/documents/term.pdf (access: 20.02.2018).

5 J. Neider, D. Marciniak-Neider, Przewozy intermodalne w transporcie międzynarodowym, WUG, Gdańsk 1992.

6 Europe 2020: A strategy for smart, sustainable and inclusive growth, European Commision, Brussels, March 2010, COM(2010) 2020 final version, p. 11, 18.

7 The White Book - Plan utworzenia jednolitego europejskiego obszaru transportu - dażenie do osiagnięcia konkurencyjnego i zasobooszczędnego systemu transportu, European Commision, Brussels, 28.03.2011, $\operatorname{COM}(2011) 144$ final version. 
in all member countries" ${ }^{\prime \prime}$. The political objective of the undertaken and declared actions is to transform the EU transport system until 2050 in effective, consistent and functioning in accordance with the principles of sustainable development.

According to the European Union 2020 Strategy: A strategy for smart, sustainable and inclusive development, the focus on sustainable development undertaken by the entire group and individual countries belonging to it should be to support a more resource-efficient, more environmentally friendly and more competitive economy. At the EU level, the European Commission declared accelerating the implementation of strategic projects with high added value from Europe, aimed at unloading the largest overloads, above all on cross-border sections and intermodal nodes, and presenting legislative proposals on modernizing the transport sector and reducing its share in carbon emissions, which will contribute to increasing competitiveness.

\section{Characteristics of road and rail transport in Poland}

According to the Central Statistical Office (Poland) data for 2016, 1836.7 million tons of freight were transported by all modes of transport, and transport work in the amount of 385.7 billion ton-kilometers. Rail transport (excluding maneuvering work) accounted for $12.1 \%$ of the total transported mass of goods, with respectively $84.2 \%$ for road transport 9 .

Table 1. Share of selected transport modes (in tons) in Poland in 2004-2016

\begin{tabular}{|c|c|c|c|c|c|c|c|c|c|}
\hline \multirow{2}{*}{$\begin{array}{c}\text { Type } \\
\text { of Transport }\end{array}$} & \multicolumn{9}{|c|}{ Year } \\
\hline & 2004 & 2006 & 2008 & 2010 & 2012 & 2013 & 2014 & 2015 & 2016 \\
\hline Rail & 21.4 & 19.7 & 15.0 & 13.1 & 12.9 & 12.6 & 12.4 & 12.4 & 12.1 \\
\hline Road & 79.2 & 75.2 & 80.9 & 83.1 & 83.4 & 84.1 & 84.1 & 83.5 & 84.2 \\
\hline
\end{tabular}

Source: own elaboration based on: CSO data

Table 1 presents the change of the structure of freight transport by rail and roads between 2004 and 2016. It is possible to observe a systematic decrease in the share of rail transport in the total weight of transported goods, with the simultaneous increase in the share of mass transported by road. At least several reasons can be found for increasing the attractiveness of road transport at the expense of rail transport. Firstly, the development of the road network in Poland, especially the highways belonging to the European corridors. In the case of investments in railway infrastructure, works relate primarily to investments in the already existing railway network, which temporarily limits its capacity. This leads to a reduction in commercial speed and higher transport costs. Secondly, the road network is much better developed and has more transport accessibility. Road transport is less demanding in terms of specialized infrastructure (sidings, terminals, devices for unloading railway wagons) and access to it (railway network capacity, track

$8 \quad$ Ibidem, p. 9.

9 Transport. Wyniki działalności w 2016 roku, Central Statistical Office, Warsaw 2017, p. 47-48. 
closures, lack of electrification of part of the railway network). Thirdly, the departure from the energy policy, which was primarily transported by rail. While still in 2004, 152000 tons of coal and briquettes were transported by rail and in 2016, respectively, 89600 tones. The share of coal in the total weight of goods transported by rail decreased from $50.7 \%$ in 2004 to below $42 \%$ from $2009^{10}$. In 2004, 282.9 million tons were transported by train, in 2016222.5 million tons, which was a decrease of $21.3 \%$. In the case of road transport, in the same period, the transported weight increased by $61.6 \%$ from 956.9 million tons to 1546.6 million tons. The volume expressed in ton-kilometers in 2016 constituted $14.7 \%$ of the total transported weight in the transport of the European Union (EU 28), which placed Poland in the second position (behind Germany). Poland in international transport, with a share of over $25 \%$, was the European leader ahead of Spain and Germany ${ }^{11}$.

After 2004, investments in the area of transport infrastructure supported by European funds focused to the greatest extent on road infrastructure. Entry into the Schengen area and the systematically improving condition of road infrastructure and relatively low labor costs have become an opportunity for Polish entrepreneurs. Since the beginning of the $21^{\text {st }}$ century, except for 2009, the value of foreign trade has been growing in Poland, which has its impact on the demand for transport work. In addition to the increasing road transport work, the number of registered lorries also systematically increased, as shown in Table 2.

During the 12 years between 2004 and 2016 almost 1 million trucks arrived in Poland. Calculated per 1000 inhabitants, the ratio increased year-on-year reaching the value from 59 in 2004 to 83 in 2016 . The number of vehicles with a load capacity of over 1.5 tons was also systematically growing, with the percentage of this type of vehicles in relation to all registered lorries after 2008 the year was shrinking. A decrease in the percentage of vehicles up to 5 years old can also be observed.

Table 2. Characteristics of equipment for trucks and public roads in Poland in the years 2004-2016

\begin{tabular}{|l|c|c|c|c|c|c|c|c|c|}
\hline \multirow{2}{*}{ Description } & \multicolumn{9}{|c|}{ Year } \\
\cline { 2 - 10 } & 2004 & 2006 & 2008 & 2010 & 2012 & 2013 & 2014 & 2015 & 2016 \\
\hline Trucks (in mln) & 2.26 & 2.25 & 2.51 & 2.77 & 2.92 & 2.96 & 3.04 & 3.10 & 3.18 \\
\hline Per 1000 inhabitants & 59 & 59 & 66 & 72 & 76 & 77 & 79 & 81 & 83 \\
\hline $\begin{array}{l}\text { With a load capacity of over } \\
1.5 \text { tonnes (in \%) }\end{array}$ & 21.6 & 21.7 & 22.5 & 21.6 & 21.1 & 21.2 & 21.0 & 21.0 & 20.9 \\
\hline $\begin{array}{l}\text { Vehicles up to 5 years old } \\
\text { (in \%) }\end{array}$ & 35 & 22 & 17.7 & 17.2 & 16.1 & 14.6 & 13.8 & 12.7 & 11 \\
\hline Public roads in 1000 km & 379.2 & 382.6 & 383.3 & 406.1 & 412.0 & 415.1 & 417.0 & 419.6 & 420.2 \\
\hline $\begin{array}{l}\text { Trucks per 1 km of public } \\
\text { roads }\end{array}$ & 6.0 & 5.9 & 6.6 & 6.8 & 7.1 & 7.1 & 7.3 & 7.4 & 7.6 \\
\hline
\end{tabular}

Source: own elaboration based on: CSO and Local Data Bank

In particular, the first years of Poland's membership in the European Union were characterized by a relatively high rate of "new" trucks. This percentage dropped

${ }_{10}$ Data based on the Central Statistical Office.

11 Transport. Wyniki dziatalności w 2016 roku..., p. 53. 
from 35\% in 2004 to $11 \%$ in 2016. The reason for this phenomenon can be seen in the slow saturation of the Polish market in trucks.

Increasing the number of trucks on Polish roads went unevenly along with the growth of public roads. The number of kilometers of public roads between 2004 and 2016 increased by $10.8 \%$. The ratio reflecting the number of trucks per 1 kilometer of public roads increased significantly, which in the corresponding period increased by $26.8 \%$. This demonstrates the increasing burden of the transport network in Poland by trucks and thus with an increasing burden on the natural environment and inhabitants of Poland.

\section{Transport of trailers and trucks by rail in Europe}

In both Poland and throughout Europe, the most popular form of intermodal transport due to the transport unit is container transport. In Eurostat statistics, unlike the Office of Rail Transport statistics, container transport is included with the transport of interchangeable undercarriages. In this category in 2004 over 154000 tons of goods were transported, while in 2016 over 234500 tons of goods, which was an increase of $52 \%{ }^{12}$.

Much less popular forms of intermodal transport are transports of trailers and trucks. In the case of transport of trucks (with driver) by rail in 10 out of 28 examined EU countries either this form of intermodal transport did not occur at all, or values in some years were below 1000 tons, so they were not recorded in Eurostat. Transportation of trucks by rail is a relatively popular form of transport only in 5 European countries (Austria, Germany, Slovenia, Switzerland and Italy), mainly due to the terrain. Especially traveling by rail through tunnels in the Alps is saving time for car carriers. The declining popularity of truck transport by rail is systematically reduced by the amount of transported tons. While in 2010, a total of 26105 thousand people were transported in 8 European countries. tons, in 2016 already with the participation of only 5 European countries transported tonnage fell to 18047 thousand. tone.

Table 3. Transport of trailers by rail in selected European countries in thousand tons in the years 2004-2016

\begin{tabular}{|l|r|r|r|r|r|r|r|r|r|}
\hline \multirow{2}{*}{ Country } & \multicolumn{9}{|c|}{ Year } \\
\cline { 2 - 11 } & \multicolumn{1}{|c|}{2004} & 2006 & \multicolumn{1}{c|}{2008} & 2010 & 2012 & 2013 & 2014 & 2015 & \multicolumn{1}{c|}{2016} \\
\hline Austria & 1309 & 1252 & 2020 & 3436 & 3486 & 6752 & 7065 & 7999 & 8637 \\
\hline $\begin{array}{l}\text { Czech } \\
\text { Republic }\end{array}$ & 0 & 12 & 15 & 70 & 369 & 529 & 588 & 605 & 671 \\
\hline Denmark & 967 & 638 & 718 & 1115 & 1191 & 1357 & 1092 & 1128 & 1306 \\
\hline Finlan & 0 & 271 & 227 & 133 & 79 & 66 & 0 & 0 & 0 \\
\hline France & 2546 & 2678 & No data & 1837 & 1078 & 1029 & 1313 & 1803 & 1749 \\
\hline
\end{tabular}

12 Based on Eurostat data. Statistical data is not complete. In 2004, there were no data for 3 countries, i.e. Bulgaria, Cyprus and Malta; in 2016, data was not available for 5 countries, i.e. Cyprus, Malta, Luxembourg, Croatia and Belgium. 
Table 3. cont.

\begin{tabular}{|l|r|r|r|r|r|r|r|r|r|}
\hline \multirow{2}{*}{ Country } & \multicolumn{9}{|c|}{ Year } \\
\cline { 2 - 11 } & 2004 & 2006 & 2008 & 2010 & 2012 & 2013 & 2014 & 2015 & \multicolumn{1}{c|}{2016} \\
\hline Netherlands & 162 & 81 & 14 & No data & 34 & 39 & 96 & 524 & 512 \\
\hline Germany & 2730 & 5770 & 6934 & 9874 & 10984 & 13041 & 17422 & 21441 & 24233 \\
\hline Norway & 1311 & 2330 & 1279 & 1206 & 1821 & 1598 & 1499 & 1642 & 1696 \\
\hline Poland & 0 & 0 & 0 & 1 & 48 & 130 & 355 & 568 & 548 \\
\hline Switzerland & No data & No data & 1807 & 2349 & 2788 & 2508 & 2796 & 3150 & 3655 \\
\hline Sweden & 1543 & 2260 & 2610 & 3945 & 3719 & 4123 & 4086 & 4339 & 4162 \\
\hline Hungary & 38 & 46 & 154 & 386 & 270 & 357 & 367 & 507 & 825 \\
\hline Italy & 2893 & 2470 & No data & 4443 & 9554 & 5752 & 10299 & 10579 & 11018 \\
\hline
\end{tabular}

Source: Eurostat

In the case of transport of trailers without a driver (Table 3), in 200412.25 million tons were transported (in EU 28), in 201654 million tons, which represented an increase of over $440 \%{ }^{13}$. This proves the growing popularity of this type of transport throughout Europe. European leaders are Germany, who transported by rail in 2016 more than twice as many trailers than others in this ranking of Italians. The transport of trailers and trucks is popular in the Alpine countries. The countries of Central and Eastern Europe such as the Czech Republic, Poland and Hungary look promising.

The share of transport volume in intermodal transport in Poland is gradually increasing. In 2004 transport work carried out with the use of intermodal transport accounted for $1.87 \%$ of the total carriage work by rail. Before the economic crisis in 2008 , it reached $4.29 \%$, as a result of the crisis it dropped to $3.32 \%$ and since then it grew again to reach $8.77 \%$ in $2016^{14}$. In 201414714 trailers were transported, which accounted for $2.1 \%$ of all units transported by intermodal transport, in 2015 the share increased to 3.7\% (27 730 units) and in 2016 it decreased to $2.7 \%$ (25817 units). The volume of transported trucks by rail in Poland was minor: 27 units in $2004(0.004 \%), 775$ in $2005(0.1 \%)$ and 62 in $2016(0.01 \%)^{15}$.

\section{Barriers and recommendations}

The increasing tonnage transported in Poland by intermodal transport with the use of trailers results mainly from the implementation of international projects. The rail market in Poland is the second largest after the German market. In 2015 in Poland, 50.6 trillion ton-kilometers (tkm) were transported by rail, with

13 Based on Eurostat data. In 2004, there were no data for Bulgaria, Cyprus and Malta. In 2016, there were no data for Cyprus, Malta, Belgium, Estonia, Ireland, Croatia and Luxembourg.

14 Analysis of railway intermodal transport in Poland, Office of Rail Transport, Warsaw 2012, p. 14; Railway transport statistics, Office of Rail Transport annual reports, https://www.utk.gov.pl (access: 22.02.2018).

15 Analysis of railway intermodal transport in Poland, Office of Rail Transport, Warsaw 2016, p. 4; Przewozy intermodalne w 2016 roku. Podsumowanie prezesa UTK, Department of Railway Market Regulation, Office of Rail Transport, Warsaw 2017, p. 4. 
$116.6 \mathrm{tkm}$ in Germany and $34.3 \mathrm{tkm}$ in France ${ }^{16}$. The size of the Polish railway market, the increasing number of trucks with limited transport infrastructure capacity, growing Polish trade and the geographical location of the country should constitute pressure and prerequisites for the development of intermodal transport, in particular the transport of trailers. The greater use of rail transport in Poland is connected with many barriers hampering the development potential of this type of transport. The most important barriers are presented in Table 4 .

Table 4. Barriers to the development of intermodal transport in Poland

\begin{tabular}{|l|l|}
\hline \multicolumn{1}{|c|}{ Barriers } & \multicolumn{1}{c|}{ Example } \\
\hline Legal and organizational & $\begin{array}{l}\text { Relatively few periodic prohibitions of truck traffic on roads, access } \\
\text { to the profession, the structure of enterprises in road transport, } \\
\text { insufficiently developed point infrastructure }\end{array}$ \\
\hline $\begin{array}{l}\text { Resulting from the delivery's } \\
\text { punctuality }\end{array}$ & $\begin{array}{l}\text { Transshipment, lower commercial speed in rail transport, track } \\
\text { closures }\end{array}$ \\
\hline Cost & $\begin{array}{l}\text { Costs of maneuvering and service in terminals, costs of access } \\
\text { to infrastructure }\end{array}$ \\
\hline
\end{tabular}

Source: own elaboration

Barriers have been divided into three groups, with cost barriers being the most important group. Legal and organizational limitations and resulting from the punctuality of deliveries ultimately come down to higher transport costs and lower attractiveness to road transport.

The legal and organizational limitations in the development of transport of trailers and lorries by rail include insufficient legal solutions that would induce or encourage entrepreneurs to redirect part of the car transport to rail. While in some EU countries on weekends there is limited traffic in road transport, in Poland such rules apply only to selected days. However, the advantage of rail transport is the relatively lower demand for work than in road traffic, the regulations limit access to the train driver's objections. Both the costs of obtaining the right to drive a traction vehicle and the time of eligibility (about 2 years) constitute a barrier to access to this profession. Another barrier of a legal nature is the inclusion of intermodal transport for freight transport, which is associated with their lower priority when awarding the route. This is reflected in unfavorable scheduled driving times and stops on the trail. The insufficiently developed point infrastructure is an obstacle to the smooth performance of railway transport. Investments in the reconstruction of the railway network have meant that a large part of the so-called passing and parking tracks, which limits parking spaces on the route, among others in anticipation of a free slot in the terminal. Also, the structure of enterprises in road transport has an impact on the interest in moving some of the transports to rail. After 2007, the largest group (over 45\%) were enterprises with 10 to 19 vehicles $^{17}$. In $2016,93 \%$ of all enterprises in commercial car transport had less than 50 trucks ${ }^{18}$.

\footnotetext{
16 Transport in figures, Statistical Pocketbook 2016, European Commission, Luxembourg 2017, p. 42.

17 Enterprises in commercial car transport by number of owned trucks and tractor units.

18 Data for the Central Statistical Office, Transport. Operating results for the years 2004-2016.
} 
In the economic interest of small and medium-sized enterprises, it is not the resignation from own transport for rail transport.

The advantage of road transport is the provision of a service from the loading point to the unloading point. In the case of railways, there is still time necessary to perform railway maneuvers, reloading and other terminal services. Probably the most important limitation for the development of intermodal transport in Poland is low commercial speed. In 2014, the average speed for intermodal transport in international transport was at the level of $35 \mathrm{~km} / \mathrm{h}^{19}$, for national transport it was $28 \mathrm{~km} / \mathrm{h}$ and for all freight transport it was $23 \mathrm{~km} / \mathrm{h}^{20}$. Difficulties are numerous track closures resulting mainly from the modernization of transport infrastructure, which increase the cost of the service performed due to the extended driving time or the need to travel a particular part of the network.

The cost barrier in the development of intermodal transport is the relatively high cost of access to infrastructure compared to other EU countries. The same intermodal discount of $25 \%$ of the route costs is not enough to increase the attractiveness of intermodal transport in Poland. The Office of Rail Transport conducted a simulation in 2016, which shows that the railway can be more competitive only in cases where the majority of road transport is performed on paid sections. On routes where there is no toll system, the railway cannot compete with road transport when it comes to costs.

The recommendations refer to the infrastructure manager of PKP PLK S.A. and legislative power. In the case of the first addressee, intermodal transport should be treated equally with passenger transport in terms of access to routes and their development. When making investments, the infrastructure manager should pay more attention to stabling tracks and other point infrastructure. The costs of access to road and rail infrastructure should equalize the chances of both modes of transport. In addition, due to the limited capacity on the main trade routes (e.g. east-west axis) or between the largest centers, it would be advisable to build new railway lines running as parallel as possible to the present, divided into a freight and passenger route. The authorities of the country can point to the need to adjust the law to EU standards in the field of air quality. One of the possible ways is limiting access of trucks to cities and promoting the transport of road transport over a distance of more than $300 \mathrm{~km}$ per railways. Another solution would be to cover all public roads with a viaToll electronic payment or another form of leveling the chances of rail and road transport.

\section{Conclusions}

The European Union policy promotes sustainable transport, of which railway transport is an important part. After 2004, a constantly increasing number of trucks can be observed in Poland, which are increasingly burdened with road infrastructure and contribute to external costs incurred by the state budget. An alternative

19 The transport of semi-trailers and lorries in Poland took place exclusively in international traffic.

20 Analysis of railway intermodal transport..., p. 12. 
to road transport is the transport of trailers and trucks by rail. Transport of trucks by rail in Europe is popular only in mountainous areas and its share in intermodal transport is declining. However, the transport of trailers is becoming more and more popular. Poland, due to its geographical location, relatively high demand for transport services and the railway network as well as the second largest railway market in Europe, has the potential to increase the share of transport of trailers in all rail transports. An obstacle in the development of this type of intermodal transport is primarily cost barriers, but also due to insufficient incentives and legal solutions that would promote rail transport. The low commercial speed in rail transport and the ongoing modernization of rail networks on a large scale limit the competitiveness of rail transport. In order to increase the role of intermodal transport in freight transport, legal changes would be recommended to level the chances of road and rail transport, especially in the area of fees for access to infrastructure. On the side of the rail infrastructure manager PKP PLK S.A. it would be recommended to include intermodal transport in the category of passenger transport and appropriate investments in point infrastructure to increase commercial speed and access to intermodal terminals.

\section{References}

Analysis of railway intermodal transport in Poland, Office of Rail Transport, Warsaw 2016. Analysis of the intermodal railway transport market, Office of Rail Transport, Warsaw 2012. Black W.R., Sustainable Transportation: A U.S. Perspective, Journal of Transport Geography 2006, 4 .

Central Statistical Office, Transport. Operating results 2004-2016, Warsaw.

Economic Commission for Europe, Terminology on combined transport, New York/Geneva 2001. Europe 2020: A strategy for smart, sustainable and inclusive growth, European Commission, Brussels, March 2010, COM (2010) 2020 final.

European Commission, Sustainable transport, https://ec.europa.eu/transport/themes/sustainable_en (access: 20.02.2018).

Eurostat, http://appsso.eurostat.ec.europa.eu/nui/show.do?dataset=rail_go_contwgt\& lang $=$ de (access: 20.02.2018).

Intermodal transport in 2016, Summary of the President of UTK, Department of Railway Market Regulation.

Local Data Bank, https://bdl.stat.gov.pl/ (access: 20.02.2018).

Neider J., Marciniak-Neider D., Przewozy intermodalne w transporcie międzynarodowym, WUG, Gdańsk 1992.

OECD Guidelines towards Environmentally Sustainable Transport, OECD, Paris 2002.

Office of Rail Transport, annual reports, https://www.utk.gov.pl (access: 18.02.2018).

Stawiński M., Przewozy intermodalne. Transport drogowy vs. kolej, Analiza UTK, Warsaw 2016.

The White Book - Plan utworzenia jednolitego europejskiego obszaru transportu - dążenie do osiagnięcia konkurencyjnego i zasobooszczędnego systemu transportu, European Commision, Bruksela 28.3.2011, COM(2011) 144 final version.

Transport in figures. Statistical Pocketbook 2016, European Commission, Luxembourg 2017.

\section{Corresponding author}

Paweł Wacek can be contacted at: pawac@wp.pl 